Article

\title{
Russia's Narratives of Global Order: Great Power Legacies in a Polycentric World
}

\author{
Alister Miskimmon ${ }^{1}$ and Ben $\mathrm{O}^{\prime}$ Loughlin $^{2, *}$ \\ ${ }^{1}$ School of History, Anthropology, Philosophy and Politics, Queen's University Belfast, Belfast BT7 1NN, UK; \\ E-Mail: a.miskimmon@qub.ac.uk \\ 2 Department of Politics and International Relations, Royal Holloway University of London, Egham TW20 0EX, UK; \\ E-Mail: ben.oloughlin@rhul.ac.uk \\ * Corresponding author
}

Submitted: 2 May 2017 | Accepted: 14 July 2017 | Published: 29 September 2017

\begin{abstract}
This article takes a strategic narrative approach to explaining the current and likely future contestation between Russia and the West. We argue that Russia projects a strategic narrative that seeks to reinforce Russia's global prestige and authority, whilst promoting multilateral legal and institutional constraints on the other more powerful actors, as a means to ensure Russia stays among the top ranking great powers. To illustrate this we analyze Russia's identity narratives, international system narratives and issue narratives present in policy documents and speeches by key players since 2000 . This enables the identification of remarkably consistency in Russia's narratives and potential points of convergence with Western powers around commitment to international law and systemic shifts to an increasingly multipolar order. However, we explain why the different meanings attributed to these phenomena generate contestation rather than alignment about past, present and future global power relations. We argue that Russia's historical-facing narratives and weakened material circumstances have the potential to hamper its adaptation to rapid systemic change, and to make attempts to forge closer cooperation with third parties challenging.
\end{abstract}

\section{Keywords}

Cold War; international order; Russia; strategic narrative; United States

Issue

This article is part of the issue "Narratives of Global Order", edited by Matthew Levinger (George Washington University, USA) and Laura Roselle (Elon University, USA).

(C) 2017 by the authors; licensee Cogitatio (Lisbon, Portugal). This article is licensed under a Creative Commons Attribution 4.0 International License (CC BY).

\section{Introduction: Strategic Narratives of Order}

Russian narratives of the international system serve as a public deliberation on Russia's role in the world, as a projection of state power, and as a means to exert persuasive force in international relations. Within Russia's narrative of the international system lie debates over Russia's post-Cold War role in the Euro-Atlantic area, and more fundamental discussions concerning how power transition in the world will affect Russia's position in it. Strategic narratives are a means to seek to shape conditions to be conducive to Russian political, economic and secu- rity interests - and these narratives are in turn defined by material conditions. However, strategic narratives go beyond expressions of material interests. They are a core component of the Russian state itself-shaping its own self-conception and setting expectations on Russia's role in the world and how it should be recognised. This essay argues that Russia projects a strategic narrative that seeks to reinforce Russia's global prestige and authority, whilst promoting multilateral legal and institutional constraints on the other more powerful actors, as a means to ensure Russia stays among the top ranking great powers. This narrative of international order has been largely con- 
sistent since the turn of the $21^{\text {st }}$ century, corresponding to Vladimir Putin's tenure as President and Prime Minister of the Russian Federation.

However, great power influence is not necessarily an accurate image of how world order operates. The EU's rhetorical shift towards value pluralism in its dealings with third parties, the uncertainties of US foreign policy under the Trump administration, and the increasing voice of emerging powers in global governance all indicate a shift to polycentrism, but not the kind envisaged by Russia. A world in which some issues are handled regionally, some intergovernmentally, and some with civil society or corporations participating in decision-making is a world of 'variable geometry' requiring a mutual refinement and flexibility of narratives across these domains (Burke-White, 2015, p. 6). Instead of the UN Security Council P5 governing world affairs hierarchically, akin to the 'fixed geometry' of the $19^{\text {th }}$ Century European congress, it is likely that, structurally, $21^{\text {st }}$ Century governance will be more fluid, based around issuefocused, regional and cross-regional coalitions. We argue it will be easier for the EU and NATO to adapt their narratives of the international system to this material situation as they invest considerable effort in projecting strategic narratives of the evolving international system as a means to influence its emergence and shape it to their material interests. Russia's historically-facing narrative could well prove out of step with the systemic change underway. It will be especially difficult for Russia to become a 'good citizen' and play a constructive role (cf. Lo, 2015), despite Russian leaders' statements concerning shared responsibility for transnational problems. Nevertheless, our concern remains that all sides must seek some narrative convergence for cooperation to be possible at all.

This article deploys the concept of strategic narrative. We define strategic narratives as 'a means by which political actors attempt to construct a shared meaning of the past, present, and future of international politics to shape the behavior of domestic and international actors' (Miskimmon, O’Loughlin, \& Roselle, 2017, p. 6). Within the literature, political narratives focus on time sequence (Shenav, 2006), the projection of a past-presentfuture structure, some attempt at resolution, and a notion that events are connected in non-random and possibly causal, or at least explicable, manner. Further, drawing on Kenneth Burke's work we examine the interaction between agency and narrative-how people use language to act (1966) - in this case, how Russian elites draw on narratives to exert influence. Narratives contain a pentad of components: character or actors (agent); setting/environment/space (scene); conflict or action (act); tools/behavior (agency); resolution/or suggested resolution/goal (purpose). We focus on these components in our analysis of Russia's strategic narrative of the international system as a means to illustrate attempts by Russian actors to influence current events, narrate Russia's role in the world and seek to shape emerging conceptions of the international system.

Strategic narratives in international affairs come in three interconnected forms. First, narratives of the international system outline how the world is structured, who the main players are, and how the system should function (Bially Mattern, 2005; Hurrell, 2005; Miskimmon \& O'Loughlin, 2017). Second, identity narratives shape perceptions of what is appropriate for a state to do in any given context. Finally, policy narratives outline how an actor views the appropriate response to address a political challenge or crisis and articulates a position based on material interest, and/or, what is might be a normatively desirable outcome. In today's interconnected world, policy narratives often compete within complex multilateral contexts, but if successful, can forge consensus between disparate positions. This article primarily addresses system narratives but they cannot be understood in isolation from the identity and policy narratives they interact and intersect with.

The final aspect of strategic narrative analysis is a focus on the nexus between international relations and communication through understanding the processes of formation, projection and reception of narratives. As we shall see in the analysis to follow, news media can amplify and reinforce narrative mis-alignment. Most recently, this takes the form of US and European media projecting an identity narrative of Russia as an intransigent autocratic state and therefore, implicitly or explicitly, propagating a 'New Cold War' system narrative.

Our analysis will demonstrate that analysing Russian narratives can only suggest superficial points of convergence between Russia and the West, ${ }^{1}$ as a starting point for debates about more fundamental conceptual differences which must be addressed before major disagreements can be recognised and accounted for. Russian leaders communicate about points of connection with the West, yet have also been keen to stress Russian civilizational and cultural singularities. The West, however, largely understands international law and democracy to have universal normative and technical characteristics. The Russian model of plural civilisations undermines the possibility of a shared normative basis for institutions. A failure to recognise that democracy, law and economic freedom are essentially contested concepts marks a failure in the West to understand that alternative explanations are structurally inevitable because of how concepts work nationally and internationally (see for example, Acharya, 2014; Callahan, 2008; Mishra, 2017). Kupchan argues that rather than follow the existing order, rising powers will seek to revise that $\operatorname{order}(2012$, p. 7). This rapidly changing picture has the potential to impose significant adaptation costs on powerful states. But as Lo (2015) argues, Russia's understanding of these concepts and the translation of them in to institutions and actions is not fit for today's global diffusion of power (cf. Slaughter, 2005, 2017).

\footnotetext{
${ }^{1}$ The West is a contested term. For a more thoughtful discussion of the term's genealogy and uses, see Gow (2005) and Hellmann and Herborth (2016).
} 
Since Wendt's (1999) assertion that international order was constructed and not given, there has been significant interest in how order is manufactured and developed in international affairs. In her book Power in Concert, Mitzen (2013) argues that the emergence of concert diplomacy in the $19^{\text {th }}$ Century established public commitments to self-restraint and collective problem-solving. Whilst the Concert of Europe ultimately collapsed, it suggested a blueprint for future generations of diplomats concerning the possibility for diplomacy to mitigate instability in global order. Creating order requires narrative work. Order is an idea that has evolved over time, taking new forms and involving different shapers through the course of history. Historian David Armitage suggests that 'what humans have invented, they may well yet dismantle; that what intellectual will has enshrined, an equal effort of imaginative determination can dethrone' (Armitage, 2017, p. 11). This is central to our understanding of how global order and narrative intersect.

After the initial post-war period during which there was the potential for cooperation, Russia and the West can now more easily be drawn into the old binary imaginary. Risse (2011, p.603) argues:

the world of 2010 still resembles the cold war and its end. The main structuring forces are still ideas and discourses. The only difference is that the world is no longer structured along only two competing discourses, Western liberalism and Eastern communism. Many more ideas now fight for attention and compete for persuasive power. And this must not be bad for international order. The transatlantic community-and the scholarly community, too-just need to get used to it. Whether the ideational plurality results in a materially multipolar order with many power-balancing centers or in a more pluralistic but still multilateral order, remains to be seen. In the end, it is still a world 'of our (discursive) making'. (Onuf, 1989)

The strategic narrative framework can explain that how the international system is understood directly effects how the international order functions. Examining how different actors project and contest narratives of the international system highlights how existing and emerging powers seek to impose a shared meaning of how international order does, or should, function. At this point of rapid systemic change, the major point of debate is the issue of recognition, rather than domination and redistribution. This is particularly so for Russia; recognition is a powerful theme running through its foreign policy narrative.

What follows is a breakdown of Russia's strategic narrative of the international system, Russia's identity and role within this desired system, and the policy prescriptions it privileges. The narratives are drawn from foreign policy documents and speeches by key players since 2000 focusing on Russia's global strategy and security policy (on the utility of analyzing Russian foreign policy texts, see Dyson \& Parent, 2017). After an initial parsing for Burke's pentad to identity narrative components, in this article we highlight narratives pertaining to Russia's international system narrative. This encompasses projections of prestige, equality and mutual respect between Russia and the West, a narrative purporting to reject stereotypes of the West and Russia, narratives of polycentrism and multipolarity, narratives of normative diversity, narratives of order based on international law, and finally, narratives of the Common European Home which draws a clear line to negotiations at the end of the Cold War which included Russia at the top table of European order. Following Roselle's $(2006,2017)$ analysis of Russia's strategic narrative, we argue that narrative divergence is complicating the emergence of narrative alignment on system narratives. This significance of this finding is to explain why the opportunity for cooperation between the West and Russia on policies that would forge closer cooperation have become increasingly difficult.

\section{Russia's Consistent System Narrative}

There has been considerable interest in the targeted use of strategic communication in Russia foreign policy, most notably in Ukraine since 2014. This is largely tactics-focused and ignores discussions on Russian strategic narratives and the Kremlin's wider efforts to shape a conducive international context for Russian foreign and domestic interests. The themes in Russia's strategic narrative of global and regional order since 2000 have been consistent. These themes include demands for recognition of Russia's standing in the world by the West, the stressing of pan-European cooperation under the Common European Home narrative, and a stress on the emergence of a new world order based on polycentrism, which will be discussed in more detail below. Jutta Weldes' idea of a 'security imaginary' is useful in this regard, understood as a, 'structure of well-established meanings and social relations out of which representations about the world of international relations are created' (Weldes, 1999, p. 10). Drawing on Weldes, Stefano Guzzini (2016) argues that the resurgence of geopolitics, with its spatial logic, serves as a means to cope with the anxiety caused by the end of the Cold War in the identities of actors in Europe. Russian elites have drawn on a defined security imaginary as a response to Russia's identity crisis following the end of the Cold War and the dissolution of the Soviet Union. How actors use narratives is central to this. The consistency of the narration of Russia's environment, and its role within it, serves as a means to reinforce Russia's post-Cold War identity. This largely historically-facing narrative of the international system provides the basis on which Russia, in debates with the West, seeks to reinforce itself domestically and how it justifies its actions internationally (Cadier \& Light, 2015; McDonald, 2007).

We argue that events in Ukraine are at least as much symptom as the cause of tensions between Russia and 
the West. A major underlying issue is a failure of Russia and the West to reach a common understanding of the international system. Russia has been coherent in how it has narrated its position in the world, and consistent in its view of international order and its desired relationship with the West-even as, Bobo Lo (2015) contends, the Kremlin narrative rests on a misunderstanding of its role in the world and of how shifts in the international system affect Russia (Stent, 2015). Russian strategic narrative consistency rests on the eternal dilemma of political elites in international affairs - whether to be driven by a realistic response to emerging events, or to strive for what they seek as what should be. The post-Cold War order in Europe has emerged from debates in the immediate aftermath of the fall of the Berlin Wall and have been reinforced by the enlargement of NATO and the EU to the borders of the former Soviet Union area. Legro (2005) suggests that at major critical junctures in international affairs states are faced with decisions on whether to adapt to new circumstances or consider alternative policy options. Rather than being a co-constitutor of this emerging system, since the early 1990s Russia has complained of being excluded from the major decisions affecting it. As time has passed, Kremlin frustration at this exclusion has triggered increasingly assertive action on their part, most notably in Ukraine, to unilaterally defend what it perceives to be in its vital national interest.

However, the intensity of the narratives has increased along with the stakes as the international system evolves. Narratives on Russia from outside the Russian Federation have often been used to reinforce Russia's perceived weakness vis-à-vis the West or powerful rising powers such as China. Former United States President Barack Obama sought to paint Russia as a weakened power, despite efforts by Putin to assert Russia's strength. In a wide-ranging interview in The Atlantic, Obama argued that Putin is

constantly interested in being seen as our peer and as working with us, because he's not completely stupid. He understands that Russia's overall position in the world is significantly diminished. And the fact that he invades Crimea or is trying to prop up Assad doesn't suddenly make him a player. You don't see him in any of these meetings out here helping to shape the agenda. For that matter, there's not a G20 meeting where the Russians set the agenda around any of the issues that are important. (Obama in Goldberg, 2016)

Conversely, there is a significant literature and policy discussion driven by concerns that the Russian Federation poses a real risk to regional and global security, and to the interests of the West. Legvold (2017, p. 1026; see also Legvold, 2016) argues that Russia is intent on challenging the existing order and that the West has underestimated its threat. Dimitri Trenin, Director of the Carnegie Moscow Center, argues that in order to avoid conflict with Russia a more nuanced view of the nature of the challenges is needed (Trenin, 2016). Trenin argues that within Russia grievances against the West fall in to two narratives: that the West fails to recognise Russia's contribution towards ending the Cold War, and that the West does not acknowledge Russia's Great Power status. From the West's perspective, Russia's actions in Crimea and more broadly in Ukraine, and the perception that Russia has been operating significant information campaigns against the West, have precipitated a Western need to rethink its relations with the Russian Federation, which, in Sperling and Webber's (2016) analysis, has involved a re-securitisation of relations, escalating the attendant risks of re-creating a security dilemma between the two sides. Narrative contestation of identities, views of regional and global order and emerging policy developments have central to understanding the emergence of the tensions now evident between the West and Russia (Pantti, 2016).

On the surface, Russian and Western narratives converge in highlighting the importance of international law, democracy and the centrality of markets. Russian Foreign Minister, Sergei Lavrov, suggests that

There's no ideological differences as far as democratic principles and market economy are concerned. Second, these days, unlike the days of the Cold War, we have much clearer common threats, like terrorism, like chaos in the Middle East, like the threat of the proliferation of weapons of mass destruction. (as cited in Saunders, 2017).

They face common threats which incentivise cooperation due to their transnational nature. From this perspective there appear to be major incentives for Russia to play an active role in tackling these threats and maintaining the pillars of international order. There is a flip side, however: Russia's expectation that, in playing a cooperative role in maintaining the architecture of the international system and addressing systemic threats, Russia will be considered a partner by the West and emerging powers. However, divergence on the meaning of the core pillars of the system-law, democracy and markets-pinpoints where the challenges for communication exist. Those outside Russia may simply not believe Lavrov when he says Russia's ideological affinity to 'democratic principles' reflects the same affinity in the West, for instance. This drives a cycle of mis-communication, embedding frustration on all sides (Hill, 2016). The result is moves towards meaningful shared governance and convergence only deepen that frustration. There is superficial convergence in the public narratives Russia projects, but this masks significant differences resting on contested understanding of core concepts of sovereignty and hierarchy in the international system.

The reception of Russia's narrative has been viewed differently in the US, triggering debates regarding competing policy responses. This reinforces our argument 
that conceptual differences matter. Let us point to four within the US. Rudolf (2016) highlights three schools in the US discussion on Russia. First, a neo-containment school which argues that a more authoritarian Moscow will pursue an expansionist policy. Second, the mechanistic school-Russia is acting like a great power vis-àvis its periphery, which should mean that the US and its partners respond more robustly to Russian actions. Third, an interactionist school that argues both sides are to blame for recent tensions and should work to forge closer cooperation. Each of these entails a narrative, projecting a past, present and possible futures. Additionally, fourth, on the global level, demands for Russian and Chinese spheres of influence counter the US-led conception of a liberal order based on integration into the existing global economy (Ikenberry, 2009). Acceptance of such a narrative would mean that the US will either have to live with this, or challenge this-which could lead to escalation.

Media ecology matters here too: The reception of Russia's foreign policy narrative in the US is complicated, Tsygankov (2017) argues, by news media which reinforce binary relationship between the US-Russia as a means to reassert US identity and global presence. Analysis of European news media shows the same has happened since 2014 (Ojala, Pantti, \& Kangas, 2017). The representation of Moscow as a neo-Soviet autocracy ignores alternative understandings of Russia in US media. This purposively juxtaposes a more inferior Russian identity with a superior American one. Tsygankov adds that the centralisation of Russian governance could be interpreted a means to address significant domestic and international challenges, rather than the portrayal of an autocratic state. Tsygankov argues:

The presentation of Russia as an abusive autocracy is a way to promote a particular image of democracy within a global competition over the power to shape information and generate ideas. In this brave new digital age, media, more than ever, are a critical tool of global governance and soft power. (Tsygankov, 2017, p. 31)

In summary, there are consistent aspects of how Russia and its elites narrate Russia's identity, its position (and grievances) within the post-Cold War order, and its vision for a future Great Power-led multipolar system. However, these narrative elements are not straightforwardly recognised outside Russia, particularly in the US; as Tsygankov suggests, what for Putin is the necessary consolidation of domestic governance appears, externally, as the actions of an autocratic and therefore problematic state (for example assassinating or jailing political opponents and invading neighbouring states). We now turn to an analysis of Russia's main strategic narratives which are central to Russian foreign policy and Vladimir Putin's conception of regional and global order.

\section{Narratives of Recognition: The Prestige, Equality and Mutual Respect Narrative}

Central to understanding Russia's narrative of the international system is the role of great powers working in concert, an elite group of states reinforcing a hierarchy to which Russia claims membership. In the National Security Concept (NSC) of the 10 January 2000 (NSC, 2000) Russia's status in the world is placed central to its foreign policy narrative and narrative of global order. The NSC 2000 states that, 'Russia is one of the world's major countries, with a centuries-old history and rich cultural traditions' (NSC, 2000) This claim to great power status is reinforced in the Foreign Policy Concept (FPC) of 28 June 2000, highlighting its position as one of the largest Eurasian powers. The FPC 2000 is laden with identity narrative claims signalling Russian responsibility to play an active role in solving international challenges, on a regional and global level. The FPC 2000 proposes that, 'the Russian Federation has a real potential for ensuring itself a worthy place in the world'. The document also outlines that Russia is a 'reliable partner', that it plays a 'constructive role' in resolving problems and that its foreign policy is 'balanced' due to its geopolitical situation. The FPC 2000 also asserts Russia's independence, pragmatism and transparency, taking into account 'legitimate interests of other states and [Russia] is aimed at seeking joint decisions'. The NSC 2000 and FPC 2000 both highlight the centrality of Russia's demand for recognition.

In a speech to the Russian International Affairs Council in June 2014, Lavrov presented the Ukraine crisis as a chance to clear the air and to focus on the modalities of what recognition of Russian concerns and status should involve. Lavrov hoped

the current crisis will become a kind of 'refreshing storm', which will help to transfer our relations with western partners to healthier and fairer foundations (probably not at once). It will probably have less tormenting discussions about the search for general values and more recognition of the right to be different, more aspirations to build relations on firm foundations of equality, mutual respect and consideration of each other's interests. (Lavrov, 2014b)

The FPC of 30 November 2016 is more explicit in outlining a narrative of recognition and reinforces the more assertive trajectory of Russia's foreign policy narrative evident particularly after the 1999 Kosovo War and 2003 Iraq War. These were viewed as being evidence of the West's disregard for international law, the sovereignty of states and a deliberate attempt to sideline Russia. The FPC 2016 puts the consolidation of the 'Russian Federation's position as a centre of influence in today's world' at the centre of Russian foreign policy (FPC, 2016, para. 3c). The mutual recognition and respect narrative of Russian foreign policy has developed over time. It was something Russia aspired to on the basis of the sleight felt 
by the West's expansion in Europe and move to an interventionist foreign policy, and as something to aspire to as Russian foreign policy recovered from the collapse of the Soviet Union in the 1990s. In recent years, the narrative has taken on a more conditional element: Russia demands recognition as a precondition for cooperation. Russian Foreign Minister Sergey Lavrov has repeatedly used this conditional narrative of recognition in his public pronouncements. In a 2014 interview Lavrov stated that, 'It is evident that the transfer to a brand new, higher level of partnership may be reached only on the basis of equality, mutual respect and consideration of each other's interests' (Lavrov, 2014a, Kommersant). Lavrov's speech to the 2017 Munich Security Policy conference reinforced this recognition narrative when outlining his view of USRussian relations: 'We want relations based on pragmatism, mutual respect, and understanding of our special responsibility for global stability' (Lavrov, 2017).

\section{Narratives of Inclusion and Exclusion: The Common European Home}

A second core Russian strategic narrative is that of the Common European Home which expresses decades-long resentments over the failure to fully include Russia in the post-Cold War European order. Symptomatic of the West's rejection of the Common European Home narrative is Russia's exclusion not only from western institutions, but also in debates concerning the growing membership of NATO and the EU and its impact on Russia's regional interests. Exclusion has been a common narrative in Russian foreign policy documents and public speeches since the 1990s. This has also been reflected in analysis by a minority of western actors who seek to understand Russia's opposition to EU and NATO expansion (Kissinger, 2014; McGwire, 1998). Russian foreign policy documents call for indivisible security (FPC, 2016, para. 27d) rather than institutionalised demarcation in Europe. Putin's 2007 Munich Security Conference speech is often referred to as the beginning of a substantive change in policy narrative, calling for a restructuring of security cooperation on the global level (Putin, 2007). Former President Medvedev's call for a New Security Architecture in 2008 is further evidence of a more pessimistic view in Russia of the possibility of establishing closer collaboration with the West in security and defence policy. Yet despite the change in policy narrative to a more critical stance towards the West signalled by Medvedev and Putin, the core claim for inclusion in decisions on European regional order remained central to Russia's system narrative.

The exclusion of Russia from meaningful European security policy discussions has been reinforced by EU and NATO narratives on European security. From the EU and NATO's perspective, Russia's destabilising foreign policy actions in the region have contradicted the Russian government's Common European Home narrative, reinforcing the West's scepticism stance on the potential for greater cooperation. The oppositional stances taken by Russia and the West based on different material interests limit the scope for a strategic narrative to emerge which might forge common ground. Since the 2014 Ukraine crisis, the EU has undergone protracted periods of selfreflection on its relations with Russia. The EU's Global Strategy of 2016 and NATO's Newport (2014) and Warsaw (2016) summit declarations have signalled the limits of EU/NATO-Russia cooperation in the context of continued tensions over Crimea and the Donbass region. This has been reinforced by tensions over Russia's support of Assad in Syria. The identity, system and policy narratives of the EU and NATO are now firmly excluding Russia from significant cooperation, stating explicitly that Russia is no longer a strategic partner. The identity and system narratives of the EU and NATO are framed as counter to Russia's narrative. This context leaves little room to forge an inclusive Common European Home narrative and reinforces the divisible security architecture it purports to oppose. We set out these competing narratives in Table 1.

We re-emphasise that while there is superficial convergence on key concepts - the primacy of international law and the emergence of a polycentric or multipolar order, for instance-the normative foundations for any cooperation are weak because of differing meanings attributed to these concepts. The EU and, to an extent NATO, emphasise universal values policed by the international community, while Russia emphasises the universal value of sovereignty, the primacy of great powers in enforcing international law, and a plurality of normative orders or civilisations, as illustrated in the final section.

\section{Multipolarity and Polycentrism: Re-Ordering the World Narrative}

The third core narrative which is consistent in Russian foreign policy has been the promotion of the emergence of a polycentric world order. Russia's 2000 FPC stressed a narrative of multipolarity and the dangers of unilateralism. It committed Russia to working towards, 'a multipolar system of international relations that really reflects the diversity of the modem world with its great variety of interests'. More recently, reinforcing a narrative of global change is a means to challenge the systemic dominance of the US and position Russia as a shaper of this new world order (FPC, 2013, para. 3). Russia's narrative stresses the relative decline of the West and the rise of the rest. The 2013 FPC stated, 'The ability of the West to dominate world economy and politics continues to diminish. The global power and development potential is now more dispersed and is shifting to the East, primarily to the Asia-Pacific region' (FPC, 2013, para. 6). Putin's 2014 speech to the Valdai International Forum highlight the dangers of 'unipolar domination'.

The EU shares much of the same order narrative. The EU Global Strategy outlines a narrative of the world as a 'complex world of global power shifts and power diffusion' (European Union, 2016, p. 16). This order narrative 
Table 1. EU, NATO and Russian narratives of identity, order and issues.

\begin{tabular}{|c|c|c|c|}
\hline & Identity & System & Policy \\
\hline EU & $\begin{array}{l}\text { New identity narrative of an } \\
\text { emerging global player; } \\
\text { Ever closer union; } \\
\text { Demonstrates by example the } \\
\text { benefits of democracy and } \\
\text { human rights. }\end{array}$ & $\begin{array}{l}\text { World characterized by demands of } \\
\text { interdependence; } \\
\text { Relations with others central to } \\
\text { stability, based on partnership; } \\
\text { Founded on governance, rule of } \\
\text { law, democracy, human rights; } \\
\text { World increasingly contested and } \\
\text { complex-alternative narratives } \\
\text { emerging which should be } \\
\text { challenged. }\end{array}$ & $\begin{array}{l}\text { Comprehensive Approach; } \\
\text { Promoting interests and universal } \\
\text { values; } \\
\text { Russia undermining freedom, } \\
\text { sovereignty security and minority } \\
\text { rights; } \\
\text { Strategic competition with BRICS; } \\
\text { Russian aggression in Ukraine; } \\
\text { Russia acting illegally; } \\
\text { Russian hybrid war; } \\
\text { Russia no longer a 'strategic } \\
\text { partner'. }\end{array}$ \\
\hline NATO & $\begin{array}{l}\text { Defender of freedom and } \\
\text { security; } \\
\text { Proves its worth in the Cold War, } \\
\text { needs to continue proving it. }\end{array}$ & $\begin{array}{l}\text { Open, rules-based system founded } \\
\text { on sovereignty and territorial } \\
\text { integrity; } \\
\text { System increasingly defined by } \\
\text { chaos and new threats. }\end{array}$ & $\begin{array}{l}\text { Russian rejection of post-Cold War } \\
\text { order; } \\
\text { Russia waging undeclared war in } \\
\text { Ukraine; } \\
\text { Russian hybrid war; } \\
\text { Russia no longer a 'strategic } \\
\text { partner'. }\end{array}$ \\
\hline Russia & $\begin{array}{l}\text { Global Player; } \\
\text { Civilization with heritage of } \\
\text { culture and science; } \\
\text { Excluded and badly treated by } \\
\text { the West. }\end{array}$ & $\begin{array}{l}\text { New for a Common European } \\
\text { Home-A common economic and } \\
\text { humanitarian space (Putin); } \\
\text { Europe less central to world } \\
\text { order-emergence of BRICS; } \\
\text { Return of East/West confrontation } \\
\text { in Europe; } \\
\text { Polycentric world order; } \\
\text { International order should have a } \\
\text { legal framework. }\end{array}$ & $\begin{array}{l}\text { Western media propagating new } \\
\text { Cold War narrative; } \\
\text { EU/NATO not respecting freedom of } \\
\text { Ukrainian people; } \\
\text { Absence of strategic trust in } \\
\text { EU/Russia relations; } \\
\text { EU exaggerates friend/foe narrative; } \\
\text { Sanctions unjust, not merited. } \\
\text { Coup d'état in Ukraine supported by } \\
\text { outsiders; } \\
\text { West provocation and flouting of } \\
\text { international law; } \\
\text { Russia helping Ukraine overcome } \\
\text { crisis. }\end{array}$ \\
\hline
\end{tabular}

portrays the EU as an upholder of values in a world where not all states share its views - as the Russian narrative of international law has stressed for many years. The EU's response has been to seek a more common foreign policy despite Brexit and the complexities of speaking with one voice. For McFarlane, Russia is determined to play a 'holding game' until the conditions emerge for it to play a more prominent role in a pluralist international system (McFarlane, 2006, p. 57). The timeline for such a holding game could be extensive. A recent report by the Russian International Affairs Council argues that the process of moving to a new multipolar international order has stalled due to the unexpectedly strong US recovery after the 2008 financial crisis (Luzyanin et al., 2016, p. 6). Lo's critique of Russia's stance of multipolarity suggests that Russia's holding game may never end. He argues

There are few signs...that the Putin regime has come to terms with the 'inconvenient truths' of the new world disorder. It continues to frame the landscape of contemporary politics within an artificial multipolar (polycentric) paradigm. It overestimates Russia's capacity to establish itself as a regional and global player on its own narrow terms. And it believes that the future lies not in adapting to fast-changing international realities, but in hunkering down-reaffirming timehonored principles of Russian foreign policy, such as the primacy of great power diplomacy and military strength. (Lo, 2015, p. 67)

States must be willing to adjust their conceptualisations. The EU has shifted, at least rhetorically, towards value pluralism in their dealings with third parties. This is routine in contemporary international affairs. China too has adapted its concept of sovereignty as 'non-intervention' for African audiences in response to African fears of exploitation, for instance (Keuleers, 2016). This is a world of 'variable geometry' governance, in which states must copartner, mutually adjust and be open to new forms and relations of power (Burke-White, 2015, p. 6). Certainly, 
rhetorical accommodation is easier from a position of material strength and security; without those, Russia can only challenge by projecting its consistent narrative in the hope it might finally not be mis-recognised, it can get mired in contesting every crime or norm violation it is accused of (MH17), or it can take military risks. However, because of more fundamental conceptual differences, its communications will intensify mutual frustration. The UN Security Council will not and cannot simply govern world affairs like $19^{\text {th }}$ Century great powers, with Russia at the table with its own sphere of influence.

\section{Conclusion}

We have charted Russia's $21^{\text {st }}$ Century foreign policy narratives, compared them to debates in the US and to EU and NATO policy documents, and pointed to a failure of Russia and the West to reach a common understanding of the emerging international system. Consistency of the Russian narrative indicates that in spite of the current fixation with disinformation and Russian-led information warfare, Russia has been coherent in how it has narrated its position in the world, drawing on a 'security imaginary' which sets limits on how much scope for adaptation in Russia's narrative of international order there is. We have highlighted that Russia's strategic narrative of the international system is underpinned by its identity narrative and this plays out in how it narrates its policy preferences or its view of the Ukraine crisis. However, shared language concerning commitment to international law and multipolarity cannot disguise competing meanings attributed to these words within Russia and the West, making narrative convergence difficult. Without such alignment, it is impossible for all parties to reach an alignment in narrating the recent past, present problems, and the future world order that they must, somehow, govern and manage together. In particular, Russia feels mis-recognised, but articulates a vision of world order that appears unsuited to the dynamics of $21^{\text {st }}$ century power, shifting hierarchies and material conditions. Since 2000 this mis-alignment has driven a cycle of mis-communication, generating frustration on all sides and restricting the scope for cooperation. It has also sparked policy responses which espouse relative gains over forging collective agreements. The crisis in Ukraine can be interpreted as an opportunistic Russian action in the absence of a shared narrative of the European space in which Russia believes it is recognised and is seen to mutually gain from cooperation with the EU and NATO. But this is not simply a direct disagreement on crises such as Ukraine. It is reflective of competing and currently unresolved narratives of world order, which further divergence can only harden.

\section{Acknowledgments}

The authors would like to thank Professor Laura Roselle and Professor Matthew Levinger for putting this the- matic issue together, the anonymous reviewers for their very helpful comments, and also Thomas Miller for his comments on an earlier version of this paper.

\section{Conflict of Interests}

The authors declare no conflict of interests.

\section{References}

Acharya, A. (2014). The end of American world order. Cambridge: Polity.

Armitage, D. (2017). Civil wars. New Haven, CT: Yale University Press.

Bially Mattern, J. (2005). Ordering international politics: Identity, crisis, and representational force. New York, NY: Routledge.

Burke, K. (1966). Language as symbolic action: Essays on life, literature, and method. Berkeley and Los Angeles, CA: University of California Press.

Burke-White, W. W. (2015). Power shifts in international law: Structural realignment and substantive pluralism. Harvard International Law Journal, 56(1), 1-79.

Cadier, D., \& Light, M. (Eds.). (2015). Russia's foreign policy: Ideas, domestic politics and external relations. London: Routledge.

Callahan, W. A. (2008). Chinese visions of world order: Post-hegemonic or a new hegemony? International Studies Review, 10(4), 749-761.

Dyson, S. B., \& Parent, M. J. (2017, April 26). In his own words: Vladimir Putin's foreign policy analyzed. War on the Rocks. Retrieved from https://warontherocks. com/2017/04/in-his-own-words-vladimir-putins-for eign-policy-analyzed

European Union. (2016). Shared vision, common action: A stronger Europe. A global strategy for the European Union's foreign and security policy. Retrieved from https://eeas.europa.eu/top_stories/pdf/eugs_review _web.pdf

Foreign Policy Concept. (2000, June 28). The foreign policy concept of the Russian Federation. Kremlin. Retrieved from http://en.kremlin.ru/supplement/4116

Foreign Policy Concept. (2013, February 12). Concept of the foreign policy of the Russian Federation. The Ministry of Foreign Affairs of the Russian Federation. Retrieved from http://www.mid.ru/en/foreign_policy/ official_documents/-/asset_publisher/CptICkB6BZ29 /content/id/122186

Foreign Policy Concept. (2016, November 30). Foreign policy concept of the Russian Federation (approved by President of the Russian Federation Vladimir Putin on November 30, 2016). The Ministry of Foreign Affairs of the Russian Federation. Retrieved from http://www.mid.ru/en/foreign_policy/official_docu ments/-/asset_publisher/CptICkB6BZ29/content/id/ 2542248

Goldberg, J. (2016). The Obama doctrine. The Atlantic. Retrieved from https://www.theatlantic.com/maga 
zine/archive/2016/04/the-obama-doctrine/471525 Gow, J. (2005). Defending the West. Cambridge: Polity. Guzzini, S. (2016). Foreign policy identity crises and uses of 'the West'. In G. Hellmann \& B. Herborth (Eds.), Uses of 'the West': Security and the politics of order (pp. 13-36). Cambridge: Cambridge University Press. Hellmann, G., \& Herborth, B. (Eds.). (2016). Uses of 'the West': Security and the politics of order. Cambridge: Cambridge University Press.

Hill, F. (2016). Putin: The one man show the West doesn't understand. Bulletin of the Atomic Scientists, 72(3), 140-144.

Hurrell, A. (2005). Power, institutions, and the production of inequality. In M. Barnett \& R. Duvall (Eds.), Power in global governance (pp. 33-58). Cambridge: Cambridge University Press.

Ikenberry, G. J. (2009). Liberal internationalism 3.0: America and the dilemmas of liberal world order. Perspectives on Politics, 7(1), 71-87.

Keuleers, F. (2016). Stories of moral actorship: European Union and Chinese narratives towards Africa. European Foreign Affairs Review, 21(4), 517-537.

Kissinger, H. (2014, March 6). How the Ukraine crisis ends. henryakissinger.com. Retrieved from http:// www.henryakissinger.com/articles/wp030614.html

Kupchan, C. A. (2012.) No one's world. Oxford: Oxford University Press.

Lavrov, S. (2014a). Article by the Russian Foreign Minister, Sergey Lavrov, "Russia-EU: Time to decide" published in the Kommersant newspaper of 13 February 2014. The Ministry of Foreign Affairs of the Russian Federation. Retrieved from http://www.mid.ru/en/ press_service/minister_speeches/-/asset_publisher/ 70vQR5KJWVmR/content/id/76622

Lavrov, S. (2014b). Speech by the Russian Foreign Minister, Sergey Lavrov, at the meeting with members of the Russian International Affairs Council, Moscow, 4 June. The Ministry of Foreign Affairs of Russia. Retrieved from http://www.rusemb.org.uk/foreign policy/2143

Lavrov, S. (2017). Foreign Minister Sergey Lavrov's address and answers to questions at the 53rd Munich Security Conference, Munich, February 18, 2017. The Ministry of Foreign Affairs of the Russian Federation. Retrieved from http://www.mid.ru/en/foreign _policy/news/-/asset_publisher/cKNonkJE02Bw/con tent/id/2648249

Legro, J. (2005). Rethinking the world: Great power strategies and international order. Ithaca, NY: Cornell University Press.

Legvold, R. (2016). Return to Cold War. Cambridge: Polity Press.

Legvold, R. (2017). H-Diplo/ISSF, volume IX, No.12 (2017). Retrieved from http://issforum.org/ISSF/PDF/ISSFRoundtable-9-12.pdf

Lo, B. (2015). Russia and the new world disorder. London: Chatham House/Brookings Institution Press.

Luzyanin, S. G., Kortuniv, A. V., Karneev, A. N., Petrovsky,
V. E., Denisov, L. E., Huasheng, Z., ... Ze, S. (2016). Russian-Chinese dialogue: The 2016 model (Report No. 25/2016). Moscow: NPMP RIAC.

McDonald, D. (2007). Domestic conjunctures, the Russian State, and the world outside, 1700-2006. In R. Legvold (Ed.), Russian foreign policy in the twenty-first century and the shadow of the past (pp. 145-204). New York, NY: Columbia University Press.

McFarlane, S. N. (2006). The R in BRICS: Is Russia an emerging power. International Affairs, 82(1), 41-57.

McGwire, M. (1998). NATO expansion: A policy error of historic importance. Review of International Studies, 24(1), 23-42.

Mishra, P. (2017). Age of anger: A history of the present. London: Allen Lane.

Miskimmon, A., \& O'Loughlin, B. (2017, May 12-14). The disinformation distraction: Why strategic narratives are the primary force of weaponisation in the Ukraine crisis. Paper presented at War Frenzy: Exploring the Violence of Propaganda, Princeton University, Princeton, NJ.

Miskimmon, A., \& O'Loughlin, B. (2017). Understanding international order and power transition: A strategic narrative approach. In A. Miskimmon, B. O'Loughlin, \& L. Roselle (Eds.), Forging the world: Strategic narratives and international relations (pp. 276-310). Ann Arbor, MI: University of Michigan Press.

Mitzen, J. (2013). Power in concert: The nineteenthcentury origins of global governance. Chicago: University of Chicago Press.

National Security Concept. (2000, January 10). National security concept of the Russian Federation. The Ministry of Foreign Affairs of the Russian Federation. Retrieved from http://www.mid.ru/en/foreign _policy/official_documents/-/asset_publisher/CptIC kB6BZ29/content/id/589768

Ojala, M., Pantti, M., \& Kangas, J. (2017). Whose war, whose fault? Visual framing of the Ukraine conflict in Western European newspapers. International Journal of Communication, 11, 474-498.

Onuf, N. (1989). World of our making: Rules and rule in social theory and international relations. Colombia, SC: University of South Carolina Press.

Pantti, M. (Ed.). (2016). Media and the Ukraine crisis. New York, NY: Peter Lang.

Putin, V. (2007). Putin's prepared remarks at 43rd Munich conference on security policy, 12 February. The Washington Post. Retrieved from http://www. washingtonpost.com/wp-dyn/content/article/2007/ 02/12/AR2007021200555.html

Putin, V. (2014, October 24). Meeting of the Valdai International Discussion Club. Kremlin. Retrieved from http://en.kremlin.ru/events/president/news/46860

Risse, T. (2011). Ideas, discourse, power and the end of the Cold War: 20 years on. International Politics, 48(4/5), 591-606.

Roselle, L. (2006). Media and the politics of failure: Great 
powers, communication strategies, and military defeats. Houndmills: Palgrave.

Roselle, L. (2017). Strategic narratives and great power identity. In A. Miskimmon, B. O'Loughlin, \& L. Roselle (Eds.), Forging the world: Strategic narratives and international relations (pp. 56-84). Ann Arbor, MI: University of Michigan Press.

Rudolf, P. (2016, September). Amerikanische RusslandPolitik und europäische Sicherheitsordnung. SWPStudie, 17.

Saunders, P. (2017). Sergei Lavrov: The interview. The National Interest. Retrieved from http://nationalin terest.org/print/feature/sergey-lavrov-the-interview $-19940$

Slaughter, A. M. (2005). A new world order. Princeton, NJ: Princeton University Press.

Slaughter, A. M. (2017). The chessboard and the web:
Strategies of connection in a networked world. New Haven, CT: Yale University Press.

Sperling, J., \& Webber, M. (2016). NATO and the Ukraine crisis: Collective securitisation. European Journal of International Security, 2(1), 19-46.

Stent, A. (2015). The limits of partnership. Princeton, NJ: Princeton University Press.

Trenin, D. (2016). Should we fear Russia. Cambridge: Polity Press.

Tsygankov, A. P. (2017). The dark double: The American media perception of Russia as a neo-Soviet autocracy, 2008-2014. Politics, 37(1), 19-35.

Weldes, J. (1999). Constructing national interests: The United States and the Cuban missile crisis. Minneapolis, MN: University of Minnesota Press.

Wendt, A. (1999). Social theory of international politics. Cambridge: Cambridge University Press.

\section{About the Authors}
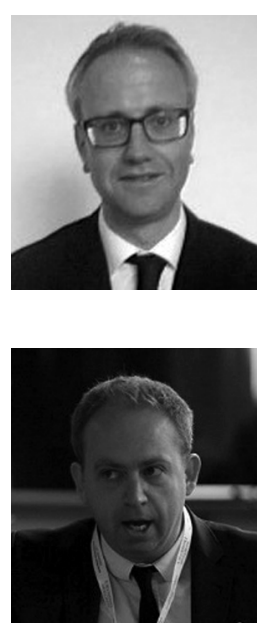

Alister Miskimmon is Head of the School of History, Anthropology, Philosophy and Politics at Queen's University, Belfast. He has published a number of books including, Strategic Narratives: Communication Power and the New World Order (New York, NY: Routledge, 2013, with Ben O'Loughlin and Laura Roselle) which was awarded the 2016 Best Book Award by the International Communication Section of the International Studies Association. His latest book with Ben O'Loughlin and Laura Roselle Forging the World: Strategic Narratives in International Relations, was published by the University of Michigan Press in 2017.

Ben O'Loughlin is Professor of International Relations and Co-Director of the New Political Communication Unit at Royal Holloway, University of London. He is Co-Editor of the journal Media, War \& Conflict. Ben was Specialist Advisor to the UK Parliament's Select Committee on Soft Power and UK Influence. $\mathrm{He}$ is currently funded by the British Council/Goethe Institute and by the European Commission to research cultural and public diplomacy in Ukraine. 